\title{
NUGGET DAN KERUPUK IKAN TONGKOL SEBAGAI ALTERNATIF USAHA UNTUK MENINGKATKAN PENDAPATAN MASYARAKAT
}

\author{
Ningrum dwi Hastuti ${ }^{1)}$, Refid Ruhibnur ${ }^{2)}$ \\ ${ }^{1}$ Politeknik Ketapang \\ email : ajeng.bima@yahoo.com \\ ${ }^{2}$ Politeknik Ketapang \\ email : refide_maldini@yahoo.com
}

\begin{abstract}
Potential outcomes catching tuna by fishermen in the village Suka Bangun Dalam this very nice with abundant results which reached an average of 7tons/day. The research objective knowledge partners want to know about the diversification of processed tuna into nuggets andchips. The methods used are education and training by means of a live demonstration of theprocessed tuna into nuggets and chips. Achievement on the training of making tuna into nuggets and chips are all participants partners to make nuggets and chips well and their packaging. The results showed that $90 \%$ of business partners can make products nuggets and chips sword fish well.
\end{abstract}

Keywords: tuna, nuggets, chips

\section{PENDAHULUAN}

Desa Suka Bangun Dalam adalah sebuah Desa yang terletak di Kecamatan Delta Pawan Kabupaten Ketapang Propinsi Kalimantan Barat merupakan daerah mayoritas masyarakat yang matapencariannya adalah sebagai nelayan, sehingga sangat potensial untuk mengolah aneka produk hasil perikanan. jarak antara Desa Suka Bangun Dalam Dengan Kabupaten Ketapang sekitar 15 KM. Wilayah Desa Suka Bangun Dalam, merupakan salah satu tempat pelelangan ikan di Daerah Ketapang. Potensi hasil penangkapan ikan tongkol para nelayan di
Desa Suka Bangun Dalam ini sangat bagus dengan hasil yang melimpah yaitu rata-rata per hari bisa mencapai 7 ton.

Ikan tongkol merupakan salah satu hasil perikanan air laut yang tidak asing lagi bagi masyarakat Indonesia. Ikan tongkol memiliki kandungan gizi yang sangat tinggi, rasanya lezat, dagingnya padat dan lembut, disamping itu harganya yang relatif lebih murah (Utomo et al., 2004). Salah satu kelemahan ikan tongkol sebagaimana yang juga dimiliki oleh komoditi hewani lainnya adalah bahwa dengan kandungan gizi seperti protein dan air yang cukup tinggi, maka memiliki sifat yang mudah busuk setelah ditangkap dan 
mati. Oleh karena itu perlu dilakukan usaha peningkatan daya simpan dan daya awet produk perikanan pada pasca panen meliputi proses pengawetan maupun pengolahan.Selain lezat dan bergizi, tongkol juga memiliki khasiat yang cukup spesifik, yaitu merangsang pertumbuhan sel-sel darah merah dan menghambat proses penuaan (Anonymous, 2010). Kandungan gizi yang tertinggi pada ikan tongkol adalah protein sebesar 48,38\% (Leksono dan Syahrul, 2001).

Nugget ikan adalah salah satu bentuk olahan dari ikan yang dapat dikembangkan. Respon konsumen terhadap nugget cukup bagus mengingat sekarang ini orang juga memperhatikan kepraktisan sebuah produk. Nugget dapat disimpan dalam bentuk beku.Pengolahan nugget juga dapat memperpanjang daya simpan daging ikan. Ikan tongkol selain diolah menjadi nugget dapat juga diolah menjadi kerupuk . Kerupuk ikan tongkol berpotensi untuk dikembangkan, karena ikan tongkol harganya lebih murah dan bergizi tinggi.

Selama ini masyarakat desa Suka Bangun Dalamhanya memanfaatkan ikan tongkol untuk dijual kepasar dalam bentuk segar (belum diolah), bahkan jika panen raya banyak yang dibuang percuma. Padahal selain dijual dalam bentuk segar (belum diolah), ikan tongkol dapat diolah menjadi nugget dan kerupukdengan sentuhan teknologi yang sederhana dan tentunya memiliki harga jual yang lebih tinggi dibandingkan dijual dalam bentuk segar (belum diolah) yang harganya naik turun sesuai dengan keinginan pasar. Hal ini terjadi karena ketidak pahaman masayarakat setempat tentang jenis produk lain yang dapat dihasilkan dari bahan baku ikan tongkol, masyarakat juga belum memahami teknologi sederhana apa yang dapat diaplikasikan pada ikan tongkol yang mereka miliki. Mereka beranggapan bahwa ikan tongkol hanya bisa jual dalam bentuk segar (belum diolah).

Lambannya akses informasi yang masuk kepedasaan dan kurangnya kepedulian masyarakat terhadap perkembangan teknologi membuat masyarakat ketinggalan informasiinformasi penting yang telah dan sedang berkembang, termasuk informasi penting mengenai teknologi tepat guna sederhana yang dapat diterapkan pada kehidupan sehari-hari. Selain itu tingkat pendidikan juga berpengaruh terhadap pola pikir kehidupan mayarakat sehingga kreasikreasi baru sulit mereka ciptakan dan 
dikembangkan. Sarana dan prasarana yang kurang, letak yang jauh dari kota juga merupakan suatu hambatan dalam penerimaan teknologi terbaru. Kenyataan inilah yang terjadi pada hampir seluruh masyarakat pedesaan termasuk nelayan di desa Suka Bangun Dalam, Kecamatan Delta Pawan Kabupaten Ketapang.

Hasil survey dilapangan menemukan harga jual tongkol $\mathrm{Rp}$. 30.000,- sampai Rp. 35.000,- per kilogram. Jika panen raya, maka jumlah tongkol semakin meningkat sebesar 1 sampai 5 ton (14-70\%), sehingga ikan tongkol tidak laku dijual dalam bentuk segar (belum diolah), bahkan ditemukan banyak jumlah tongkol yang terbuang percuma. Ditinjau dari aspek sosial budaya masyarakat setempat, banyaknya ikan tongkol yang tidak terjual atau terjual murah sangat dipengaruhi oleh kebiasaan dari nelayan pendahulunya dan belum adanya sarana prasarana yang memadai dalam mengakses informasi secara cepat untuk mengolah ikan tongkol.

Ikan tongkol yang tidak terjual bahkan sampai dibuang, secara aspek religi merupakan suatu kemubadziran yang tidak layak bila dilakukan oleh seorang yang beragama, karena agama mengajarkan pada umatnya bahwa kemubadziran adalah perilakunya syaitan. Sedangkan bila diolah, maka masyarakat setempat akan mendapatkan penghasilan. Tambahan penghasilan tersebut akan membuat masyarakat setempat lebih semangat dalam menjalankan ibadahnya dan lebih optimis dalam menyongsong masa depan.

\section{METODE PENELITIAN}

\section{Rancangan kegiatan}

Kegiatan dilaksanakan mulai dari bulan Januari hingga Nopember 2015, dimulai dari persiapan dalam tim pelaksana, mempersiapkan lokasi dan mitra kerja, pelaksanaan praktek pembuatan produk dan peninjauan keberlanjutan kegiatan.

\section{Khalayak Sasaran}

Pemilihan mitra kerja dilihat dari keseriusan, keaktifan dan keberlanjutan organisasi yang terdapat di Desa Karanganyar. Penentuan mitra kerja ini dianggap sangat penting karena menjadi salah satu indikator keberhasilan kegiatan. Subyek yang disurvei adalah nelayan ikan yang tergabung dalam kelompok Mitra Bahari dan Ibu-ibu PKK. Hasil survei yang meliputi wawancara dan observasi mengarah pada Ibu PKK dan nelayan ikan 
yang tergabung dalam kelompok Mitra Bahari sebagai mitra kerja yang sesuai.

\section{Bahan dan alat}

Bahan kerupuk meliputi, ikan tongkol, tepung tapioca, telur, garam halus, soda, gula, dan bawang putih halus, Bahan nugget meliputi, ikan tongkol, gula, MSG, merica bubuk, bawang putih, bawang bombai, telur, tepung terigu, putih telur, dan tepung roti.

Blender, freezer, sealer, dandang, kompor, pisau, talenan, sutil, bak penampungan bahan, wajan, sendok pengaduk, nampan cetakan, sepet, dan plastik kemasan.

\section{Desain dan kinerja alat}

Desain dan peralatan yang digunakan pada kegiatan ini sederhana dan lebih pada teknologi tepat guna yang dirancang sesuai dengan kondisi pedesaan, yaitu mudah digunakan, efesien dalam produktivitas, mudah dipindah-pindahkan dan mudah dalam perawatannya.

Teknik pengumpulan data dan analisis data

Pengumpulan data dilakukan dengan melakukan wawancara pada pengurus PKK dan nelayan anggota dari Mitra bahari. Pengumpulan data ini dimaksudkan untuk mengetahui status sosial, pendidikan dan motivasi mitra kerja dalam kegiatan IbM yang dilaksanakan agar target luaran dapat tercapai.

Target luaran dinilai pada saat pelaksanaan kegiatan praktek pembuatan nugget dan kerupuk ikan tongkol dan pemantauan keberlanjutan kegiatan.

\section{HASIL DAN PEMBAHASAN}

Hasil pelaksanaan kegiatan Pengabdian kepada masyarakat melibatkan dua mitra.Mitra kerja yang ikut dalam kegiatan pelatihan pembuatan produksi dan pengemasan adalah 26 orang dengan latar belakang pendidikan 10 orang SMU, 10 orang SMP dan 6 orang SD. Secara umum, pendidikan mitra kerja cukup baik dan data yang ditemui menunjukkan bahwa tidak ada seorang pun dari peserta yang pernah mengetahui cara pembuatan nugget dan kerupuk ikan tongkol.

Rendahnya pengetahuan terhadap olahan ikan tongkoldan berlimpahnya bahan baku ikan tongkol di desa Suka Bangun Dalam merupakan fenomena yang menarik perhatian tim kerja untuk melatih dan mentransfer pengetahuan pembuatan nugget dan kerupuk ikan tongkol. Tabel 1 memperlihatkan jumlah mitra kerja yang pernah membuat nugget 
dan kerupuk ikan tongkol sebelum kegiatan IbM dilaksanakan

Tabel 1. Mitra kerja yang pernah membuat nugget dan kerupuk ikan tongkol sebelum kegiatan $\mathrm{IbM}$

\begin{tabular}{lcc}
\hline & Nugget & Kerupuk \\
\hline Pernah & 0 & 0 \\
Belum & 20 & 20 \\
pernah & & \\
Jumlah & 20 & 20 \\
\hline
\end{tabular}

Tabel 2. Produk yang dihasilkan menarik, dapat dikembangkan dan bernilai jual

\begin{tabular}{lcc}
\hline & Nugget & Kerupuk \\
\hline Ya & 26 & 20 \\
Tidak & 0 & 6 \\
Jumlah & 26 & 26 \\
\hline
\end{tabular}

Tabel 3. Bahan baku mudah diperoleh dan cara pembuatan produk mudah dibuat sendiri

\begin{tabular}{lcc}
\hline & Nugget & Kerupuk \\
\hline Ya & 26 & 26 \\
Tidak & 0 & 0 \\
Jumlah & 26 & 26 \\
\hline
\end{tabular}

Mitra kerja yang berjumlah 20 orang belum pernah membuat nugget dan kerupuk ikan tongkol (Tabel 1). Setelah melaksanakan kegiatan, ternyata $90 \%$ mitra kerja dapat membuat produk nugget dan kerupuk ikan tongkol dengan baik yaitu secara fisik dan rasa nugget dan kerupuk ikan tongkol menarik, sehingga dapat dikembangkan sebagai produk olahanikan tongkol yang memberikan alternatif selain dijual dalam bentuk segar
(Tabel 2). Kondisi produk akan lebih menarik dan ketahanan produk meningkat dengan dilakukan pengolahan dan pengemasan yang benar.

Peralatan pengemasan yang dimiliki mitra kerja menjadi modal penting dalam pengembangan produk dan peningkatan nilai jual nugget dan kerupuk ikan tongkol. Dasar dalam pengembangan produk yaitu bahan dasar yaitu ikan tongkol sangat mudah didapatkan di desa Suka Bangun Dalam. Produk nugget dan kerupuk ikan tongkol juga relatif mudah di buat oleh mitra kerja pada saat pelatihan produksi (Tabel 3) dan saat peninjauan keberlanjutan kegiatan. Saat membuat nugget dan kerupuk ikan tongkol, tim pelaksana memberikan alternatif dan penjelasan yang mendasar serta sederhana. Penjelasan tersebut berkenaan dengan mitra kerja yang akan mengkonsumsi produk yang dibuat.

\section{KESIMPULAN}

Dua tahapan kegiatan pengabdian kepada masyarakat yang telah dilakukan dapat disimpulkan bahwa:

1. Seluruh mitra kerja dapat membuat nugget dan kerupuk ikan tongkol serta melakukan pengemasan dengan baik. 
2. Produk nugget dan kerupuk ikan tongkol yang dihasilkan pada pelatihan produksi menarik dan dapat dikembangkan.

3. Bahan dasar pembuatan produk nugget dan kerupuk, yaitu ikan tongkol segar yang mudah didapatkan di desa Suka Bangun Dalam

\section{REFERENSI}

Anonymous, 2010. Khasiat Daging Ikan Tongkol. http://2.bp.blogspot.com/ JXduGID8vWg/S1TcGiw9EbI/AA AAAAAAAqo/PBCXXhAyjGc/s16 00-h/Ikan Tongkol\%282\%29.htm. Diakses tanggal 1 Januari 2014

Adawyah, R. 2008. Pengolahan dan Pengawetan Ikan. Jakarta: Bumi Aksara

Ferry, A. 2009. Konflik pemanfaatan sumberdaya perikanan laut kasus nelayan di-perairan utara jawa timur http://ferragusta.wordpress.com/20 09/12/04/ Diakses 11 Januari 2014

Khomson, A. 2004. Peranan Pangan dan Gizi Untuk Kualitas Hidup. PT.Gramedia Widiasarana Indonesia: Jakarta

Leksono, T dan Syahrul. 2001.Studi Mutu Dan Penerimaan Konsumen Terhadap Abon Ikan.Jurnal Natur Indonesia 3(2):178- 184.

Suzuki, T. 1981. Fish Krill Protein Procesing Technology. Aplied Science Publisher, Ltd. London. http://www.google.co.id/. Diakses tanggal 30 Januari 2014

Utomo, A.R, Ristiarini, S.\&Reynaldo, SR., 2004. Penentuan Kombinasi Terbaik

Penambahan Maltodekstrin De-12 dan Stpp Pada Pengolahan Surimi Ikan Tonglol (Euthynnus Affinis).Seminar Nasional dan Kongres Perhimpunan Ahli Teknologi Pangan Indonesia (PATPI) 
